\title{
Prognostic value of FOXM1 in solid tumors: a systematic review and meta-analysis
}

\author{
Lijun Li, ${ }^{1,}$, Dang Wu ${ }^{2, *}$, Qun $\mathbf{Y u}^{3}$, Lingdi $\mathbf{L i}^{4}$ and Pin $\mathbf{W u}^{5}$ \\ ${ }^{1}$ Department of Surgery, Hangzhou Xixi Hospital, Hangzhou, China \\ ${ }^{2}$ Department of Radiation Oncology, Second Affiliated Hospital, Zhejiang University School of Medicine, Zhejiang University, \\ Hangzhou, China \\ ${ }^{3}$ Fourth Ward of Neurosurgery, Division of Nursing, Second Affiliated Hospital, Zhejiang University School of Medicine, \\ Zhejiang University, Hangzhou, China \\ ${ }^{4}$ Department of Oncology, Hangzhou Cancer Hospital, Hangzhou, China \\ ${ }^{5}$ Department of Thoracic Surgery, Second Affiliated Hospital, Zhejiang University School of Medicine, Zhejiang University, \\ Hangzhou, China \\ * These authors contributed equally to this work \\ Correspondence to: Lingdi Li, email: lilingdi2002413@126.com \\ Pin Wu, email: doctorwp@163.com
}

Keywords: FOXM1, solid tumors, prognosis, overall survival, disease free survival

Received: July 02, 2016

Accepted: February 20, 2017

Published: February 27, 2017

Copyright: Li et al. This is an open-access article distributed under the terms of the Creative Commons Attribution License (CC-BY), which permits unrestricted use, distribution, and reproduction in any medium, provided the original author and source are credited.

\section{ABSTRACT}

Accumulated studies have provided controversial evidences of the association between Forkhead Box M1 (FOXM1) expression and survival of human solid tumors. To address this inconsistency, we performed a meta-analysis with 23 studies identified from PubMed and Medline. We found elevated FOXM1-protein expression was significantly associated with worse 3 -year overall survival (OS) $(O R=3.30$, $95 \% \mathrm{CI}=2.56$ to $4.25, P<0.00001) 5$-year OS (OR $=3.35,95 \% \mathrm{CI}=2.64$ to 4.26 , $P<0.00001)$ and 10 -year OS $(O R=5.24,95 \% C I=2.61$ to $10.52, P<0.00001)$ of human solid tumors. Similar results were observed when disease free survival (DFS) were analyzed. Subgroup analysis showed that FOXM1 overexpression was associated with poor prognosis of colorectal cancer, gastric cancer, hepatic cancer, lung cancer and ovarian cancer. High expression level of FOXM1 was also associated with advanced tumor stage. In conclusion, elevated FOXM1 expression is associated with poor survival in most solid tumors. FOXM1 is a potential biomarker for prognosis prediction and a promising therapeutic target in human solid tumors.

\section{INTRODUCTION}

Forkhead Box M1 (FOXM1), a transcription factor of the forkhead family, is well demonstrated to be critical for proliferation, apoptosis, migration and invasion of human cancer [1]. FOXM1 is also linked to angiogenesis, cellular senescence, DNA damage response, drug resistance, cancer stem cell renewal and differentiation of cancer [2]. Recent study demonstrate the genic overexpression of FOXM1 is a major predictor of adverse outcomes across 39 human malignancies by a computational analysis of FOXM1 expression in mRNA level [3]. Some studies have demonstrated
FOXM1-targeted therapy could effectively restrain tumor development of cancer [4-7]. These evidences suggest FOXM1 may be an attractive prognostic prediction biomarker and therapeutic target for human cancers. However, the prognostic value of FOXM1-protein in human solid tumors is still controversial.

A plenty of studies showed that elevated FOXM1 expression in tumor tissue was correlated with poor survival of patients with various solid tumors such as angiosarcoma [8], breast cancer [9], cervical cancer [10], colorectal cancer [11-13], gastric cancer [14-16], hepatic cancer [17, 18], laryngeal squamous cell cancer [19], lung cancer [20-22], malignant peripheral nerve sheath tumor 
[23], medulloblastoma [24], esophageal cancer [25], ovarian cancer $[26,27]$, pancreatic cancer $[28,29]$ and renal cell cancer [30]. However, other study showed there is no significantly correlation between FOXM1 expression in tumor tissue and outcome of patients with esophageal cancer [31].

Therefore, we carried out a meta-analysis combining available evidences to evaluate the prognostic value of FOXM1 expression in solid tumors. We also evaluated whether the correlation between FOXM1 expression and outcome of patients is different between tumor types. This meta-analysis intended to assess the role of FOXM1 in relation to survival in solid tumors, thereby shed more light on the development of FOXM1-targeted therapy and prognostic prediction in solid tumor.

\section{RESULTS}

\section{Search results and study characteristics}

Twenty-three studies with a total of 2847 patients were included (Figure 1). Three evaluated gastric cancer [14-16], three evaluated lung cancer [20-22], two studies evaluated colorectal cancer $[11,12]$, two evaluated hepatocellular cancer $[17,18]$, two evaluated esophageal cancer [25, 31], two evaluated ovarian cancer [26, 27], two evaluated pancreatic cancer [28, 29], one evaluated breast cancer [9], angiosarcoma [8], cervical cancer [10], laryngeal squamous cell cancer [19], malignant peripheral

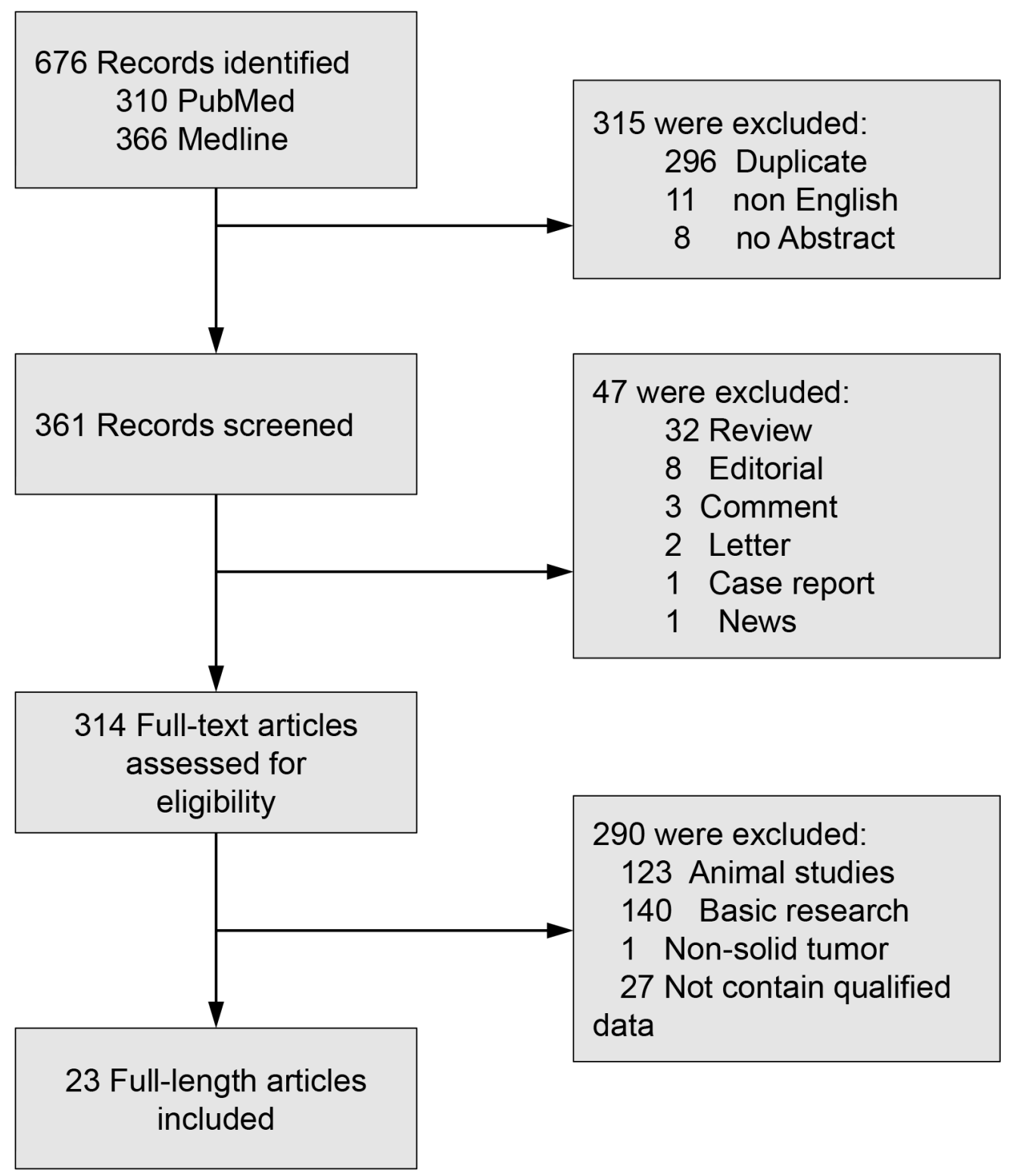

Figure 1: Flow diagram of study selection. FOXM1: Forkhead Box M1. 
Table 1: Characteristics of studies included in the meta-analysis

\begin{tabular}{|c|c|c|c|c|c|c|c|c|c|c|c|}
\hline Ref & PMID & Type of tumor & $\begin{array}{l}\text { Patient } \\
\text { No. }\end{array}$ & $\begin{array}{l}\text { Age, median } \\
\text { (range) }\end{array}$ & $\begin{array}{l}\text { Male/ } \\
\text { Female }\end{array}$ & Stage & $\begin{array}{l}\text { FOXM1 } \\
\text { (+/-) NO. }\end{array}$ & $\begin{array}{l}\text { 3-year OS } \\
(+/-) \%\end{array}$ & $\begin{array}{l}\text { 5-year OS } \\
(+/-) \%\end{array}$ & $\begin{array}{l}\text { 10-year OS } \\
(+/-) \%\end{array}$ & $\begin{array}{l}\text { NOS } \\
\text { Score }\end{array}$ \\
\hline $\begin{array}{l}\begin{array}{l}\text { Bektas, } \\
(2008)\end{array} \\
\text { N., } \quad \text { et } \quad \text { al. }\end{array}$ & 18254960 & Breast cancer & 204 & $56(25-82)$ & NR & I-III & $146 / 56$ & $80.84 / 90.92$ & $68.57 / 80$ & $53.46 / 67.3$ & 8 \\
\hline $\begin{array}{l}\text { Chu, X.-Y., et al. } \\
(2012)\end{array}$ & 22326401 & Colorectal cancer & 112 & NR & $36 / 76$ & I-IV & $57 / 55$ & $44.64 / 63.73$ & $44.64 / 55.36$ & NR & 7 \\
\hline He, S.-y., et al. (2012) & 22943878 & Cervical cancer & 102 & $43.55(26-72)$ & $0 / 102$ & I-II & $75 / 27$ & $63.33 / 82.22$ & $54.07 / 82.22$ & NR & 8 \\
\hline Hu, C.-J., et al. (2015) & 25482013 & Gastric cancer & 40 & NR & $28 / 12$ & I-IV & $26 / 14$ & $44.32 / 62.37$ & NR & NR & 6 \\
\hline $\begin{array}{l}\text { Hui, M. K. C., et al. } \\
\text { (2012)-C }\end{array}$ & 21976009 & Oesophageal cancer & 64 & NR & $47 / 17$ & I-IV & $27 / 37$ & $18.5 / 18.5$ & $9 / 18.5$ & NR & 6 \\
\hline $\begin{array}{l}\text { Hui, M. K. C., et al. } \\
\text { (2012)-N }\end{array}$ & 21976009 & Oesophageal cancer & 64 & NR & $47 / 17$ & I-IV & $16 / 48$ & $15.98 / 19.07$ & $15.98 / 12.89$ & NR & 6 \\
\hline Ito, T., et al. (2016) & 27162541 & Angiosarcoma & 107 & 66.3 & $63 / 44$ & I-IV & $28 / 66$ & $35.34 / 65.97$ & $23.82 / 47.12$ & $0 / 37.7$ & 8 \\
\hline \begin{tabular}{llll|} 
Jiang, & L.-Z., et \\
$(2011)$ & & & \\
\end{tabular} & 21334713 & $\begin{array}{l}\text { Laryngeal squamous } \\
\text { cell carcinoma }\end{array}$ & 89 & $59(33-85)$ & $78 / 11$ & I-IV & $49 / 40$ & $76.33 / 89.61$ & $57.97 / 77.78$ & NR & 8 \\
\hline $\begin{array}{llll}\text { Kong, } & \text { F.-F., et al. } \\
(2014) & & \\
\end{array}$ & 24715097 & Lung cancer & 68 & 59.44 & $38 / 30$ & I-IV & $43 / 25$ & $36.53 / 72.02$ & $11.9 / 63.05$ & NR & 7 \\
\hline Li, D., et al. (2013) & 23136192 & Colorectal cancer & 203 & NR & $86 / 117$ & I-IV & $132 / 71$ & $80.31 / 92.91$ & $49.6 / 85.9$ & NR & 6 \\
\hline Li, X., et al. (2014) & 23873251 & Gastric cancer & 103 & NR & $68 / 35$ & I-IV & $81 / 22$ & $55.34 / 77.12$ & $35.73 / 63.4$ & NR & 8 \\
\hline Ning, Z., et al. (2014) & 24993031 & \begin{tabular}{|l|}
$\begin{array}{l}\text { Pancreatic ductal } \\
\text { adenocarcinoma }\end{array}$ \\
\end{tabular} & 136 & $67(34-80)$ & $74 / 62$ & II & $86 / 50$ & $29.33 / 39.00$ & $10.56 / 26.1$ & $2.64 / 23.46$ & 8 \\
\hline Okada, K., et al. (2013) & 23054116 & Gastric cancer & 77 & NR & $52 / 25$ & NR & $53 / 24$ & $70.2 / 90.26$ & $59.6 / 90.26$ & NR & 7 \\
\hline Priller, M., et al. (2011) & 21918172 & Medulloblastoma & 41 & NR & $22 / 19$ & NR & $20 / 21$ & $42.98 / 90.73$ & $42.98 / 85.11$ & $22.75 / 84.83$ & 6 \\
\hline $\begin{array}{l}\text { Sun, H.-C., et al. } \\
(2011)\end{array}$ & 21431285 & Hepatocellular cancer & 151 & NR & $130 / 20$ & I-III & $89 / 61$ & $32.76 / 76.85$ & $32.76 / 64.29$ & NR & 8 \\
\hline Takata, A., et al. (2014) & 24778055 & Oesophageal cancer & 174 & $64(46-81)$ & $155 / 19$ & I-IV & $94 / 80$ & $44.16 / 67.51$ & $42.39 / 64.47$ & $36.8 / 61.68$ & 8 \\
\hline Wen, N., et al. (2014) & 24885308 & Ovarian cancer & 158 & $53(26-79)$ & $0 / 158$ & I-IV & $101 / 57$ & $44.37 / 68.49$ & $13.83 / 41.16$ & NR & 8 \\
\hline Wu, X.-R., et al. (2013) & 23263830 & Renal cell cancer & 87 & $56.6(24-82)$ & $60 / 27$ & NR & $37 / 50$ & $69.66 / 95.21$ & $69.66 / 79.04$ & NR & 8 \\
\hline Xia, J.-T., et al. (2012) & 22249132 & \begin{tabular}{|l|}
$\begin{array}{l}\text { Pancreatic ductal } \\
\text { adenocarcinoma }\end{array}$ \\
\end{tabular} & 80 & $59(28-78)$ & $48 / 32$ & I-IV & $53 / 27$ & $0 / 51.65$ & NR & NR & 8 \\
\hline Xia, L., et al. (2012) & 22613004 & Hepatocellular cancer & 406 & NR & $331 / 75$ & I-III & $201 / 105$ & $41.89 / 75.52$ & $27.14 / 54.28$ & NR & 8 \\
\hline Xu, N., et al. (2013) & 23536876 & Lung cancer & 175 & NR & $122 / 53$ & I-IV & $112 / 63$ & $37.58 / 84.19$ & $27.1 / 73.1$ & NR & 8 \\
\hline $\begin{array}{l}\text { Yang, D. K., et al. } \\
(2009)\end{array}$ & 19121844 & Lung cancer & 69 & $62(43-84)$ & $65 / 4$ & I-III & $26 / 43$ & $51.3 / 76.84$ & $32.14 / 76.65$ & NR & 9 \\
\hline Yu, J., et al. (2011) & 21325289 & $\begin{array}{l}\text { Malignant peripheral } \\
\text { nerve sheath tumor }\end{array}$ & 82 & NR & NR & NR & $34 / 48$ & $20.51 / 56.2$ & $13.68 / 40.81$ & $7.28 / 28.91$ & 6 \\
\hline Zhao, F., et al. (2014) & 25411964 & Ovarian cancer & 119 & NR & NR & I-IV & $53 / 29$ & $76.36 / 81.56$ & $58.44 / 77.4$ & $35.58 / 77.4$ & 6 \\
\hline
\end{tabular}

FOXM1: Forkhead Box M1; 1: Cohort 1; 2: Cohort 2; 3: Cohort 3; C: cytoplasmic expression; N: nuclear expression; OS: Overall survival.

nerve sheath tumor [23], medulloblastoma [24] and renal cell cancer [30] respectively. For the region, 20 studies were conducted in Asia, 2 studies in Europe, 1 studies in America.

\section{Evaluation and expression of FOXM1}

The major information of included studies and extracted data from the included studies were summarized in Table 1. All studies detected FOXM1 expression by IHC. There are seventeen studies used antibody of FOXM1 with clone sc-502, one study used clone K-19 and four studies did not report the antibody clone. The mean of FOXM1 positive patients in solid tumors was $56.71 \%$, range from $25 \%$ to $78.64 \%$.

\section{Association of FOXM1 with OS}

The combined analysis of 23 studies showed that FOXM1 overexpression in tumor tissue was associated with worse 3 -year $\mathrm{OS}(\mathrm{OR}=3.30,95 \% \mathrm{CI}=2.56$ to 4.25 , $P<0.00001)$, 5-year OS (OR $=3.35,95 \% \mathrm{CI}=2.64$ to 4.26, $P<0.00001)$ and 10 -year OS $(\mathrm{OR}=5.24,95 \% \mathrm{CI}$ $=2.61$ to $10.52, P<0.00001$ ) of solid tumors (Figure 2 ). Results of 8 studies showed that FOXM1 expression was associated with statistically significant poor 3-year DFS $(\mathrm{OR}=3.01,95 \% \mathrm{CI}=2.21$ to $4.12, P<0.00001)$, 5-year DFS $(\mathrm{OR}=3.22,95 \% \mathrm{CI}=2.34$ to $4.41, P<0.00001)$ and 10 -year DFS $(\mathrm{OR}=4.41,95 \% \mathrm{CI}=1.56$ to $12.43, P$ $=0.005)($ Figure 3$)$.

In the stratified analysis by tumor types, FOXM1 expression was associated with worse 3-year OS of colorectal cancer $(\mathrm{OR}=2.56,95 \% \mathrm{CI}=1.40$ to $4.69, P$ 
A

FOXM1 - FOXM1 + Odds Ratio Odds Ratio

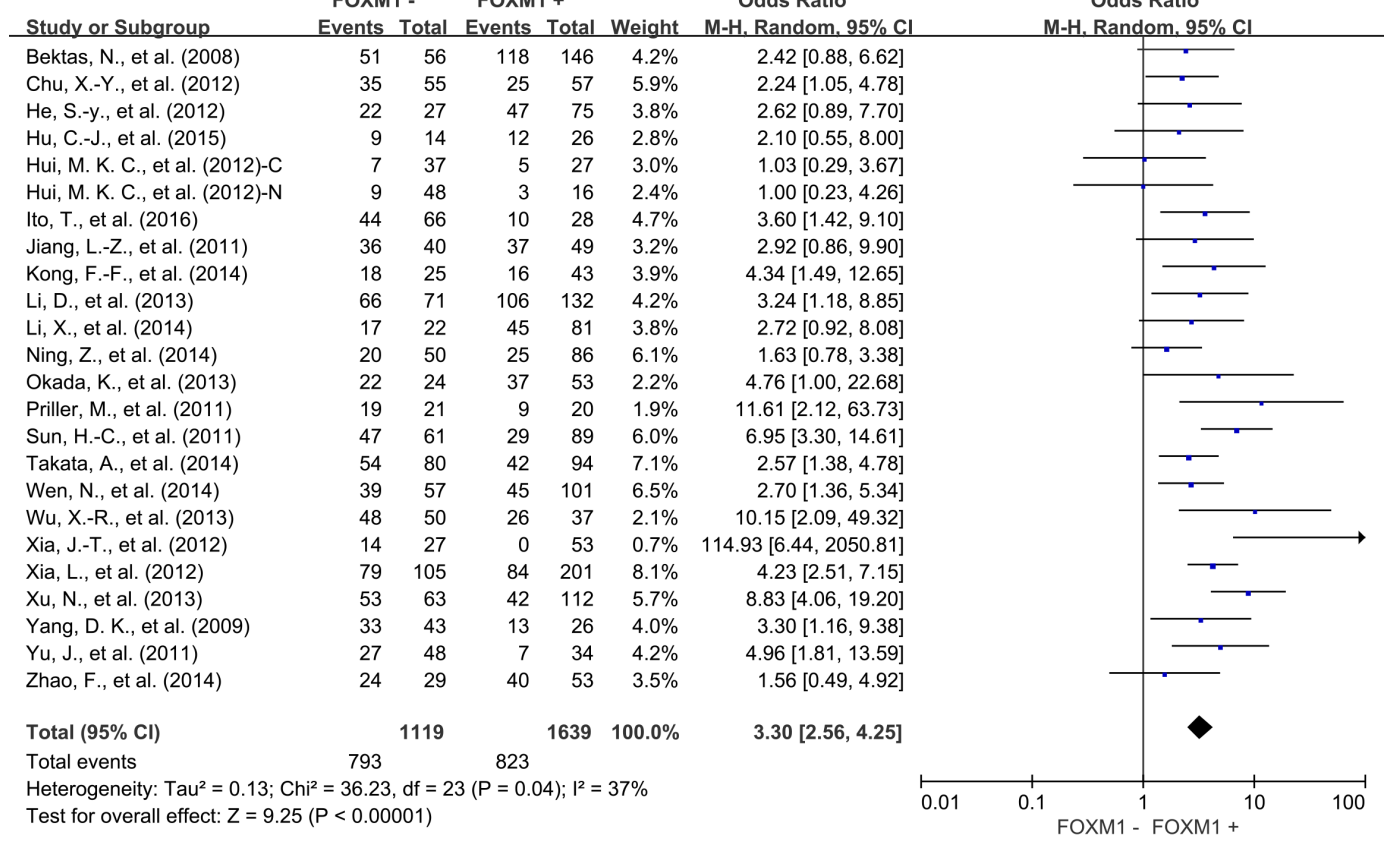

B

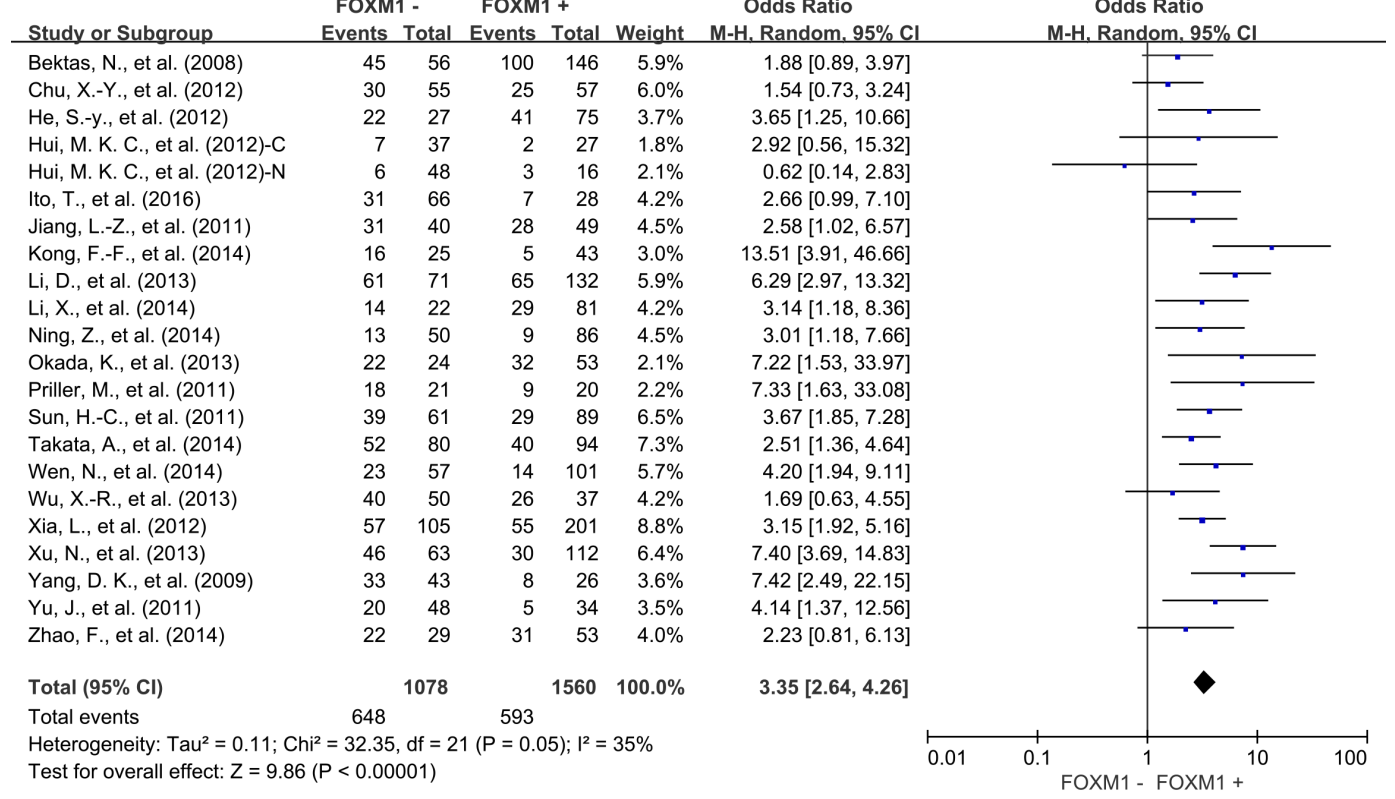

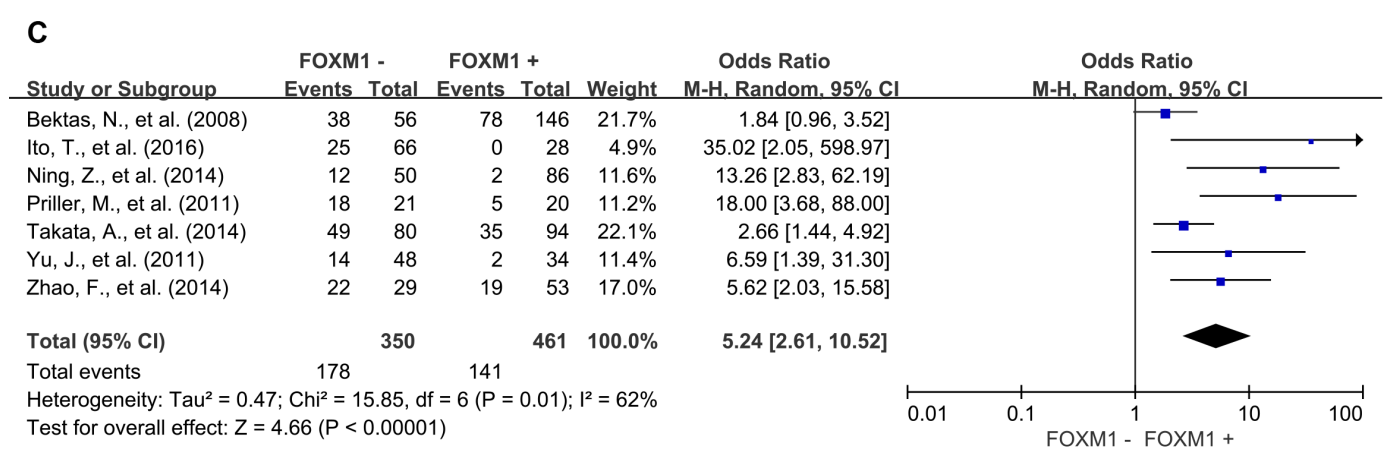

Figure 2: Overall survival (OS) according to FOXM1 expression in tumor tissue. A. 3-year OS; B. 5-year OS; B. 10-year OS. $\mathrm{C}$ : cytoplasmic expression; N: nuclear expression. 
$=0.002)$, gastric cancer $(\mathrm{OR}=2.85,95 \% \mathrm{CI}=1.36$ to 5.99, $P=0.006)$, hepatic cancer $(\mathrm{OR}=5.04,95 \% \mathrm{CI}=$ 3.17 to $8.02, P<0.00001)$, lung cancer $(\mathrm{OR}=5.51,95 \%$ $\mathrm{CI}=2.98$ to $10.19, P<0.00001)$ and ovarian cancer $(\mathrm{OR}$ $=2.34,95 \% \mathrm{CI}=1.30$ to $4.20, P=0.005$ ) (Figure 4 ). Consistent with this 3-year OS, FOXM1 expression was associated with worse 5-year OS of gastric cancer $(\mathrm{OR}=$ $3.98,95 \% \mathrm{CI}=1.74$ to $9.12, P=0.001)$, hepatic cancer $(\mathrm{OR}=3.32,95 \% \mathrm{CI}=2.22$ to $4.95, P<0.00001)$, lung cancer $(\mathrm{OR}=8.27,95 \% \mathrm{CI}=4.86$ to $14.05, P<0.00001)$ and ovarian cancer $(\mathrm{OR}=3.33,95 \% \mathrm{CI}=1.80$ to $6.15, P$ $=0.0001)$ (Figure 5). There was no significant association between FOXM1 expression and survival of esophageal cancer and pancreatic cancer (Supplementary Figure 1).

We also evaluated the correlation between FOXM1 expression and the TNM stage of tumor. High expression level of FOXM1 was significantly associated with advanced TNM stage $(\mathrm{OR}=2.78,95 \% \mathrm{CI}=1.64$ to 4.71 , $P=0.0002$ ) (Figure 6). Moreover, we found that FOXM1 overexpression in tumor tissue was also significantly correlated with the 3 -year $\mathrm{OS}(\mathrm{OR}=2.62,95 \% \mathrm{CI}=1.62$ to $4.26, P<0.0001)$ and 5-year OS $(\mathrm{OR}=3.12,95 \% \mathrm{CI}$ $=1.56$ to $6.28, P=0.001)$ of patients with cancer in early stage (Supplementary Figure 2).

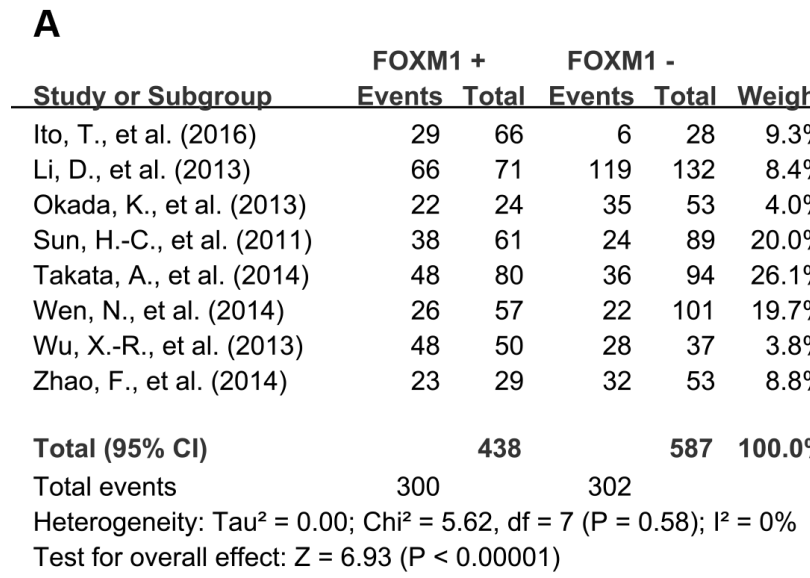

Odds Ratio Odds Ratio -H. Random. $95 \% \mathrm{Cl} \quad \mathrm{M}-\mathrm{H}$. Random. $95 \% \mathrm{Cl}$

B

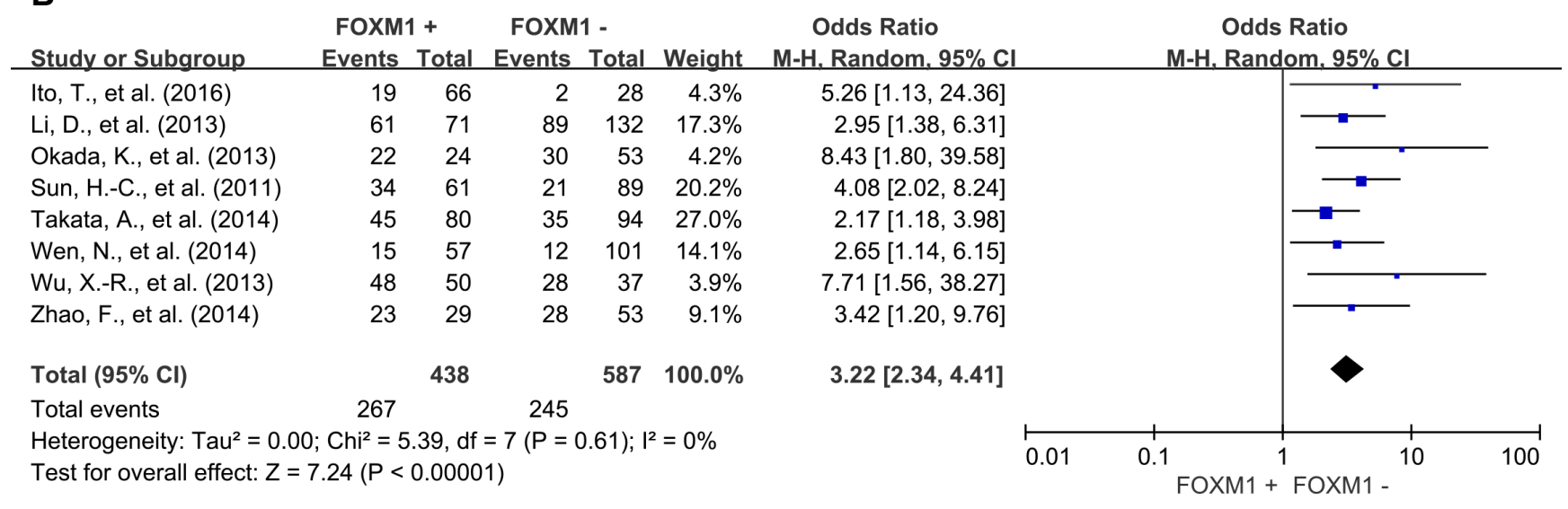

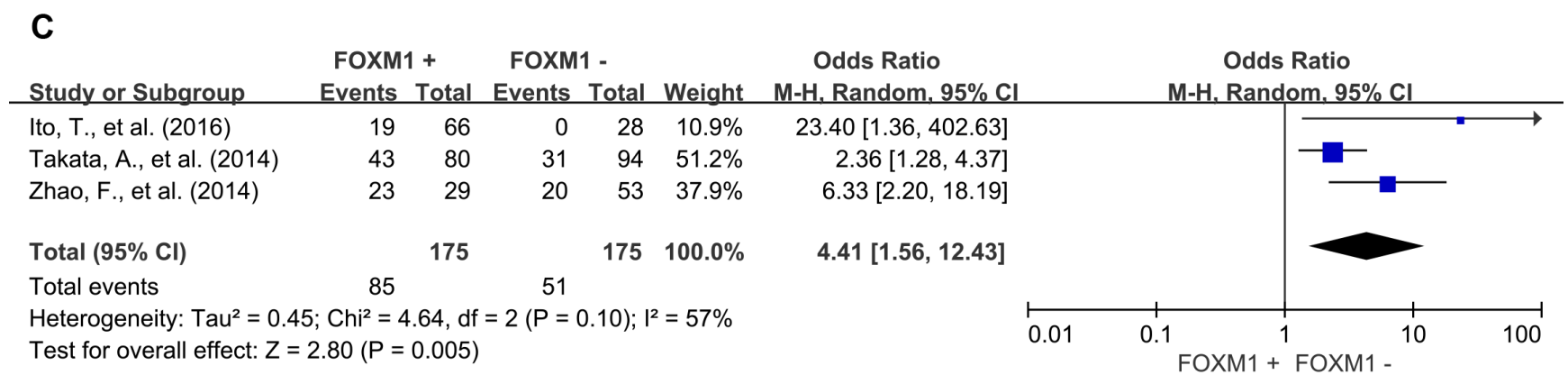

Figure 3: Disease free survival (DFS) according to FOXM1 expression in tumor tissue. A. 3-year DFS; B. 5-year DFS; B. 10 -year DFS. 
Meta-regression analysis showed that publication year, country, gender and NOS score did not contribute to the heterogeneity (data not shown).

\section{Sensitivity analyses}

Removal of the studies that was an outlier (score, IRS, $>50 \%$ ) or no report (NR) with regard to the cutoff of FOXM1 overexpression did not influence results for

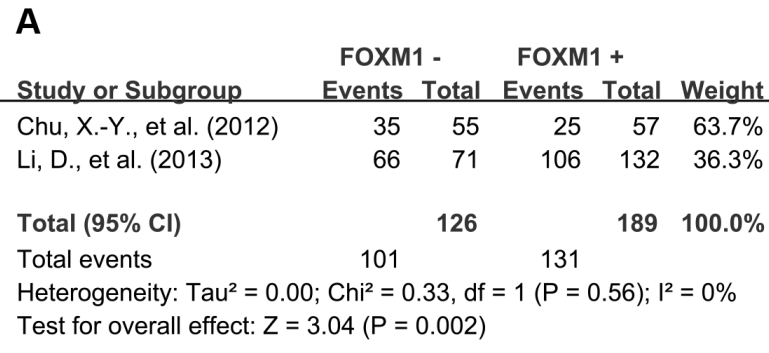

B

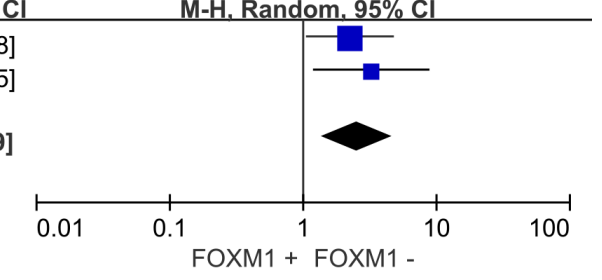

Odds Ratio M-H. Random, $95 \% \mathrm{Cl}$

C

\begin{tabular}{|c|c|c|c|c|c|}
\hline Study or Subgroup & $\begin{array}{l}\text { FOXM } \\
\text { Events }\end{array}$ & $\begin{array}{l}1 \text { - } \\
\text { Total }\end{array}$ & $\begin{array}{r}\text { FOXM } \\
\text { Events }\end{array}$ & & \\
\hline Sun, H.-C., et al. (2011) & 47 & 61 & 29 & 89 & $35.3 \%$ \\
\hline Xia, L., et al. (2012) & 79 & 105 & 84 & 201 & $64.7 \%$ \\
\hline Total $(95 \% \mathrm{Cl})$ & & 166 & & 290 & $100.0 \%$ \\
\hline Total events & 126 & & 113 & & \\
\hline \multicolumn{6}{|c|}{$\begin{array}{l}\text { Heterogeneity: } \text { Tau }^{2}=0.02 ; \mathrm{Chi}^{2}=1.14, \mathrm{df}=1(P=0.29) ;\left.\right|^{2}=12 \% \\
\text { Test for overall effect: } Z=6.83(P<0.00001)\end{array}$} \\
\hline
\end{tabular}

Odds Ratio M-H. Random, 95\% Cl $6.95[3.30,14.61]$ $4.23[2.51,7.15]$ $5.04[3.17,8.02]$ $2.10[0.55,8.00]$ $2.72[0.92,8.08]$ $4.76[1.00,22.68]$ 2.85 [1.36, 5.99]

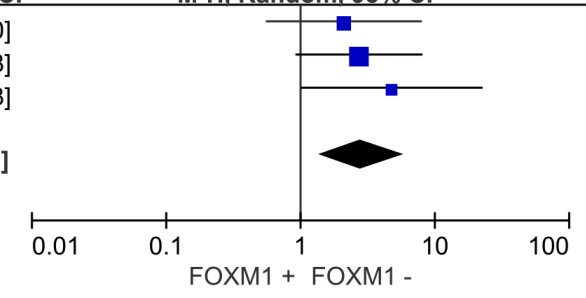

Odds Ratio M-H, Random, $95 \% \mathrm{Cl}$

Odds Ratio

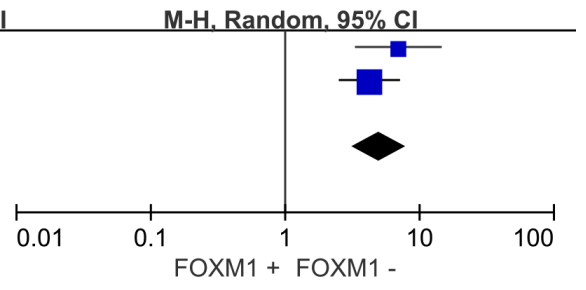

\section{D}

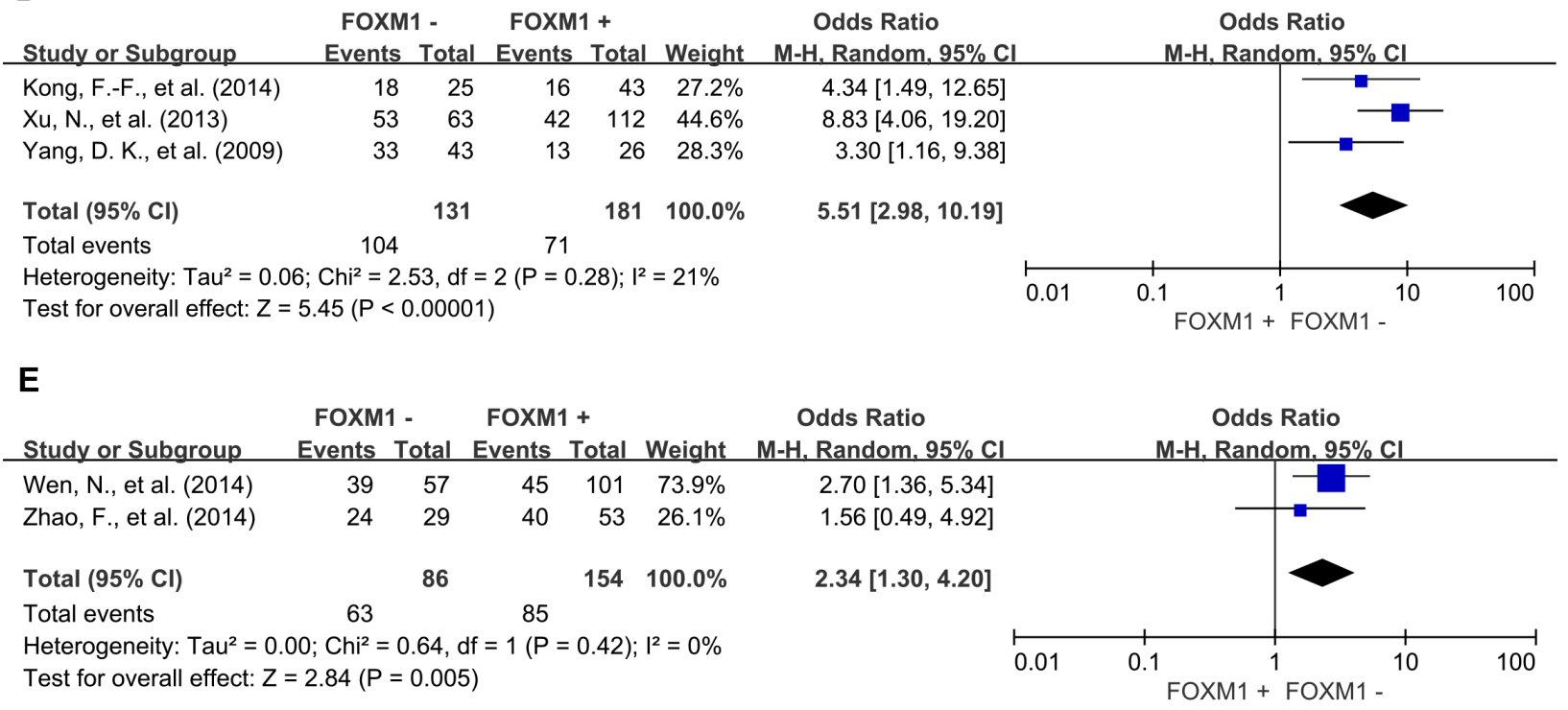

Figure 4: Subgroup analysis of 3-year OS according to FOXM1 expression in different tumor types. A. colorectal cancer; B. gastric cancer; C. hepatic cancer; D. lung cancer; E. ovarian cancer. 
3- or 5-year OS $(\mathrm{OR}=3.79,95 \% \mathrm{CI}=2.89$ to $4.97, P<$ $0.00001 ; \mathrm{OR}=3.19,95 \% \mathrm{CI}=2.54$ to $4.01, P<0.00001$; respectively). Exclusion of these studies did not reduce heterogeneity for 3- or 5-year OS (Cochran's Q $P=0.10$, $\mathrm{I}^{2}=31 \%$; Cochran's Q $P=0.24, \mathrm{I}^{2}=19 \%$, respectively).

Removal of studies with NOS score 6 did not influence results for 3- or 5-year OS (OR $=3.57,95 \% \mathrm{CI}$ $=2.70$ to $4.72, P<0.00001 ; \mathrm{OR}=3.32,95 \% \mathrm{CI}=2.56$ to $4.30, P<0.00001$, respectively). Exclusion of these studies did not reduce heterogeneity for 3- or 5-year OS (Cochran's Q $P=0.07, \mathrm{I}^{2}=37 \%$; Cochran's Q $P=0.08, \mathrm{I}^{2}$ $=35 \%$, respectively).

\section{Publication bias}

Funnel plot analysis showed that there was no statistical evidence of publication bias in our meta-analysis (data not shown).

\section{DISCUSSION}

This meta-analysis is the most comprehensive assessment of the literatures regarding FOXM1-protein expression and tumor prognosis to date. We systematically

A

\begin{tabular}{|c|c|c|c|c|c|}
\hline Study or Subgroup & $\begin{array}{l}\text { FOXM } \\
\text { Events }\end{array}$ & Total & $\begin{array}{r}\text { FOXM } \\
\text { Events }\end{array}$ & $\begin{array}{l}1+ \\
\text { Total }\end{array}$ & Weight \\
\hline Li, X., et al. (2014) & 14 & 22 & 29 & 81 & $71.4 \%$ \\
\hline Okada, K., et al. (2013) & 22 & 24 & 32 & 53 & $28.6 \%$ \\
\hline Total $(95 \% \mathrm{Cl})$ & & 46 & & 134 & $100.0 \%$ \\
\hline Total events & 36 & & 61 & & \\
\hline
\end{tabular}

Odds Ratio

Random. $95 \% \mathrm{C}$

$3.14[1.18,8.36]$

$7.22[1.53,33.97]$

$3.98[1.74,9.12]$

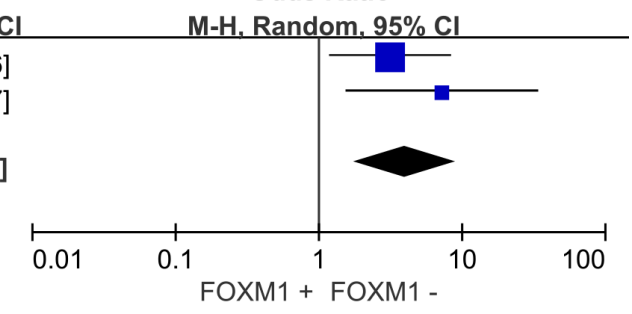

\section{B}

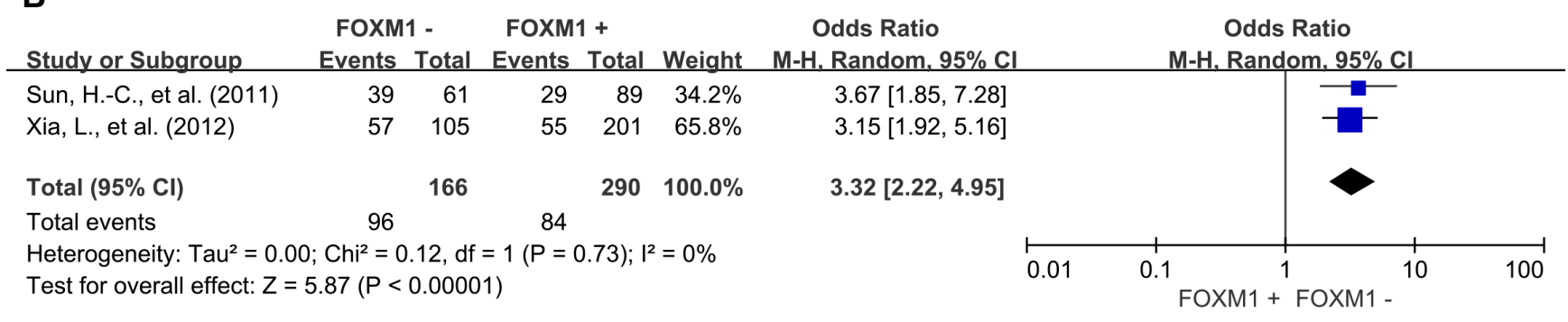

C

FOXM1 - FOXM1 + Odds Ratio Study or Subgroup Events Total Events Total Weight M-H. Random, 95\% C $\begin{array}{llllll}\text { Kong, F.-F., et al. (2014) } & 16 & 25 & 5 & 43 & 18.3 \%\end{array}$ $\begin{array}{llllll}\mathrm{Xu}, \mathrm{N} . \text {, e et al. (2013) } & 46 & 63 & 30 & 112 & 58.1 \%\end{array}$ Yang, D. K., et al. (2009)

Total $(95 \% \mathrm{Cl})$ $\begin{array}{lllll}33 & 43 & 8 & 26 & 23.6 \%\end{array}$

$13.51[3.91,46.66]$

$7.40[3.69,14.83]$

$7.42[2.49,22.15]$

Total events $131 \quad 181 \quad 100.0 \%$

Heterogeneity: $\mathrm{Tau}^{2}=0.00 ; \mathrm{Chi}^{2}=0.74, \mathrm{df}=2(\mathrm{P}=0.69) ; \mathrm{I}^{2}=0 \%$

Test for overall effect: $Z=7.80(P<0.00001)$

$8.27[4.86,14.05]$

D

FOXM1 - FOXM1 + Odds Ratio

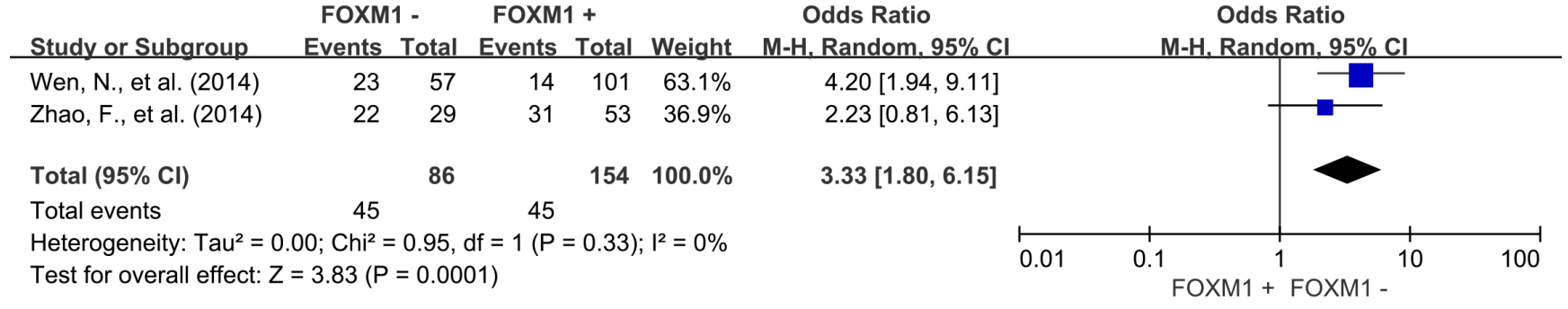

Figure 5: Subgroup analysis of 5-year OS according to FOXM1 expression in different tumor types. A. gastric cancer; B. hepatic cancer; C. lung cancer; D. ovarian cancer. 
evaluated survival data for 2847 solid tumor patients included in 23 different studies. Our study demonstrated that the expression of FOXM1 is a potential biomarker of poor prognosis in most solid tumors, with consistent results of both OS and DFS at 3, 5 and 10 years. Regarding to the tumor types, elevated FOXM1 expression in tumor tissues were associated with worse OS of most human solid tumors, such as colorectal cancer, gastric cancer, hepatic cancer, lung cancer and ovarian cancer. But FOXM1 expression is not statistical correlation with survival of esophageal cancer and pancreatic cancer. In addition, we found expression level of FOXM1 was significantly associated with advanced stage of human solid tumors. And FOXM1 overexpression in tumor tissue is also correlated with unfavorable outcome in early stage cancers.

FOXM1 is a key transcription factor, which provides a balanced transcriptional programme to ensure proper growth and maturation during embryogenesis and foetal development as well as to manage appropriate homeostasis and repair of adult tissues [32]. However, deregulated FOXM1 signalling in cancer is involved in cell migration $[33,34]$, invasion $[35,36]$, angiogenesis $[37,38]$, stem cell renewal $[39,40]$, DNA damage repair and cellular senescence [41, 42], which impact tumor initiation [43, 44], progression, metastasis, angiogenesis and drug resistance [45]. These evidences suggest that dysregulated of FOXM1 expression and FOXM1 signal pathway in tumor microenvironment may serve as a key factor in human cancer development.

Recently, a comprehensive genomics-based study included 18,000 patients demonstrated that elevated FOXM1 gene expression is correlated with adverse outcome across 39 malignancies [3]. Consistently, our meta-analysis found overexpression of FOXM1 in protein level is also significantly correlated with poor outcome of human solid tumors. These evidences highlight the potential of FOXM1 to be a valuable therapeutic target and prognostic biomarker for solid tumor.

In summary, FOXM1 expression in solid tumor tissues is associated with poor survival in most solid tumors, which suggests that FOXM1 is a valuable prognostic biomarker and a promising therapeutic target for solid tumors.

\section{MATERIALS AND METHODS}

This meta-analysis was conducted according to the statement for reporting systematic reviews and metaanalyses [46]. This study summarized and analyzed the results of previous studies, so the ethical approval was not necessary.

\section{Search strategy and study selection}

An electronic search of Pubmed and Web of Science were undertaken for studies evaluating FOXM1 expression and clinical outcome in solid tumors from 1994 to June 2016. The search was performed with subject heading terms including "FOXM1 protein, human" and "Neoplasms" and the results were limited to human studies of solid tumors. A total of 310 and 366 entries were identified, respectively. Inclusion criteria were the measurement of FOXM1 expression in tumor tissues by immunohistochemistry (IHC), availability of survival data for at least 3 years, and original article written in English. Citation lists of retrieved articles were manually screened to ensure sensitivity of the search strategy. Study selection was based on the association of FOXM1 expression and survival. Two reviewers (Lijun Li and Dang Wu) evaluated independently all of the full articles for study

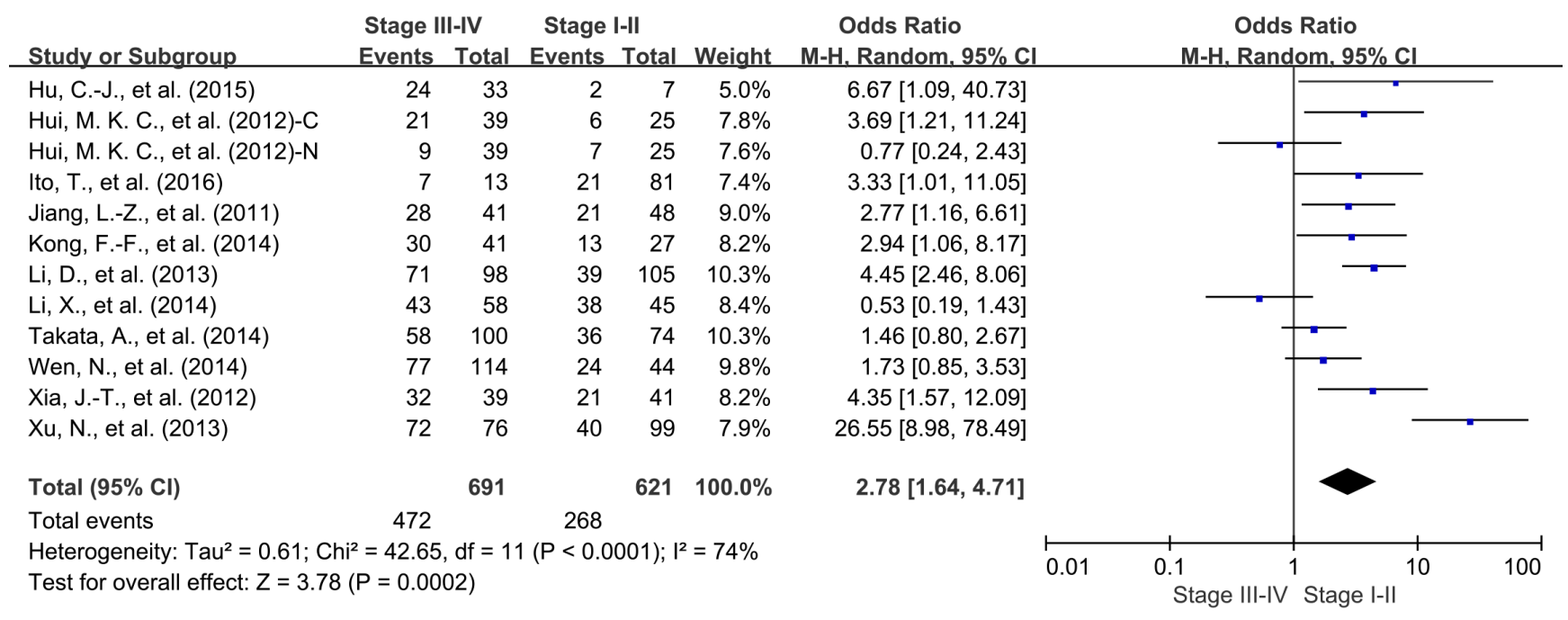

Figure 6: Correlation of FOXM1 expression and tumor stage. C: cytoplasmic expression; N: nuclear expression. 
eligibility. Inter-reviewer agreement was assessed using Cohen's kappa coefficient. Disagreement was resolved by consensus.

\section{Data extraction}

Overall survival (OS) and disease free survival (DFS) were the primary endpoints of interest. Data were extracted using predefined abstraction forms. The following details were extracted by two authors ( $\mathrm{Lijun} \mathrm{Li}$ and Dang $\mathrm{Wu}$ ): name of first author, year of publication, country of publication, tumor type, patient number, tumor stage, antibodies used for the evaluation, method and score for FOXM1 assessment, and cut-off values to determine FOXM1 positivity. Data for 3, 5 and 10 year of OS and DFS were extracted from tables or Kaplan-Meier curves for both FOXM1 negative and FOXM1 positive group.

The studies included in our meta-analysis were all cohort studies. Two independent authors evaluated the quality of each included study using Newcastle-Ottawa Scale (NOS) [47]. The studies with 6 scores or more were considered as high quality studies. A consensus NOS score for each item was achieved finally.

\section{Data synthesis}

The relative frequency of OS and DFS at 3,5 and 10 years between FOXM1 negative and FOXM1 positive group was presented as an odds ratio (OR) and its $95 \%$ confidence interval (CI). Sensitivity analyses were carried out for different analytical methods and cut-offs for defining FOXM1 expression and NOS scores for quality assessment of included studies. Publication bias was assessed by visual inspection of the funnel plot.

\section{Statistical analysis}

Data were extracted from the primary publications and combined into a meta-analysis using RevMan 5.3 analysis software (Cochrane Collaboration, Copenhagen, Denmark). Estimates of ORs were weighted and pooled using the Mantel-Haenszel random effect model. Statistical heterogeneity was assessed using the Cochran's $\mathrm{Q}$ and $\mathrm{I}^{2}$ statistics. Differences between subgroups were assessed using methods as previous described by Deeks et al [48]. Meta-regression analysis was conducted using Stata 12.0 software (StataCorp LP, College Station, TX). All statistical tests were two-sided, and statistical significance was defined as $P<0.05$. No correction was made for multiple statistical testing.

\section{ACKNOWLEDGMENTS}

This work was supported by grants from the
National Natural Science Foundation of China (81572800, PW) and Natural Science Foundation of Zhejiang Province (LY15H160041, PW).

\section{CONFLICTS OF INTEREST}

The authors declare no competing financial interest.

\section{REFERENCES}

1. Myatt SS, Lam EW. The emerging roles of forkhead box (Fox) proteins in cancer. Nat Rev Cancer. 2007; 7:847-59.

2. Lam EW, Brosens JJ, Gomes AR, Koo CY. Forkhead box proteins: tuning forks for transcriptional harmony. Nat Rev Cancer. 2013; 13:482-95.

3. Gentles AJ, Newman AM, Liu CL, Bratman SV, Feng W, Kim D, Nair VS, Xu Y, Khuong A, Hoang CD, Diehn M, West RB, Plevritis SK, Alizadeh AA. The prognostic landscape of genes and infiltrating immune cells across human cancers. Nat Med. 2015; 21:938-45.

4. Hegde NS, Sanders DA, Rodriguez R, Balasubramanian S. The transcription factor FOXM1 is a cellular target of the natural product thiostrepton. Nat Chem. 2011; 3:725-31.

5. Kwok JM, Myatt SS, Marson CM, Coombes RC, Constantinidou D, Lam EW. Thiostrepton selectively targets breast cancer cells through inhibition of forkhead box M1 expression. Mol Cancer Ther. 2008; 7:2022-32.

6. Gusarova GA, Wang IC, Major ML, Kalinichenko VV, Ackerson T, Petrovic V, Costa RH. A cell-penetrating ARF peptide inhibitor of FoxM1 in mouse hepatocellular carcinoma treatment. J Clin Invest. 2007; 117:99-111.

7. Kalinichenko VV, Major ML, Wang X, Petrovic V, Kuechle J, Yoder HM, Dennewitz MB, Shin B, Datta A, Raychaudhuri P, Costa RH. Foxm $1 b$ transcription factor is essential for development of hepatocellular carcinomas and is negatively regulated by the p19ARF tumor suppressor. Genes Dev. 2004; 18:830-50.

8. Ito T, Kohashi K, Yamada Y, Iwasaki T, Maekawa A, Kuda M, Hoshina D, Abe R, Furue M, Oda Y. Prognostic Significance of Forkhead Box M1 (FOXM1) Expression and Antitumor Effect of FOXM1 Inhibition in Angiosarcoma. J Cancer. 2016; 7:823-30.

9. Bektas N, Haaf A, Veeck J, Wild PJ, Lüscher-Firzlaff J, Hartmann A, Knüchel R, Dahl E. Tight correlation between expression of the Forkhead transcription factor FOXM1 and HER2 in human breast cancer. BMC Cancer. 2008; 8:42.

10. He SY, Shen HW, Xu L, Zhao XH, Yuan L, Niu G, You $\mathrm{ZS}$, Yao SZ. FOXM1 promotes tumor cell invasion and correlates with poor prognosis in early-stage cervical cancer. Gynecol Oncol. 2012; 127:601-10.

11. Chu XY, Zhu ZM, Chen LB, Wang JH, Su QS, Yang JR, Lin Y, Xue LJ, Liu XB, Mo XB. FOXM1 expression correlates with tumor invasion and a poor prognosis of colorectal cancer. Acta Histochem. 2012; 114:755-62. 
12. Li D, Wei P, Peng Z, Huang C, Tang H, Jia Z, Cui J, Le X, Huang S, Xie K. The critical role of dysregulated FOXM1PLAUR signaling in human colon cancer progression and metastasis. Clin Cancer Res. 2013; 19: 62-72.

13. Weng W, Okugawa Y, Toden S, Toiyama Y, Kusunoki M, Goel A. FOXM1 and FOXQ1 are promising prognostic biomarkers and novel targets of tumor suppressive miR342 in human colorectal cancer. Clin Cancer Res. 2016; 22:4947-57.

14. Hu CJ, Wang B, Tang B, Chen BJ, Xiao YF, Qin Y, Yong X, Luo G, Zhang JW, Zhang D, Li S, He F, Yang SM. The FOXM1-induced resistance to oxaliplatin is partially mediated by its novel target gene Mcl-1 in gastric cancer cells. Biochim Biophys Acta. 2015; 1849:290-9.

15. Li X, Qi W, Yao R, Tang D, Liang J. Overexpressed transcription factor FOXM1 is a potential diagnostic and adverse prognostic factor in postoperational gastric cancer patients. Clinical \& translational oncology. 2014; 16: 30714.

16. Okada K, Fujiwara Y, Takahashi T, Nakamura Y, Takiguchi S, Nakajima K, Miyata H, Yamasaki M, Kurokawa Y, Mori M, Doki Y. Overexpression of forkhead box M1 transcription factor (FOXM1) is a potential prognostic marker and enhances chemoresistance for docetaxel in gastric cancer. Ann Surg Oncol. 2013; 20:1035-43.

17. Sun HC, Li M, Lu JL, Yan DW, Zhou CZ, Fan JW, Qin XB, Tang HM, Peng ZH. Overexpression of Forkhead box M1 protein associates with aggressive tumor features and poor prognosis of hepatocellular carcinoma. Oncol Rep. 2011; 25:1533-39.

18. Xia L, Huang W, Tian D, Zhu H, Zhang Y, Hu H, Fan D, Nie Y, Wu K. Upregulated FoxM1 expression induced by hepatitis $\mathrm{B}$ virus $\mathrm{X}$ protein promotes tumor metastasis and indicates poor prognosis in hepatitis B virus-related hepatocellular carcinoma. J Hepatol. 2012; 57:600-12.

19. Jiang LZ, Wang P, Deng B, Huang C, Tang WX, Lu HY, Chen HY. Overexpression of Forkhead Box M1 transcription factor and nuclear factor- $\mathrm{B}$ in laryngeal squamous cell carcinoma: a potential indicator for poor prognosis. Hum Pathol. 2011; 42:1185-93.

20. Kong FF, Qu ZQ, Yuan HH, Wang JY, Zhao M, Guo YH, Shi J, Gong XD, Zhu YL, Liu F, Zhang WY, Jiang B. Overexpression of FOXM1 is associated with EMT and is a predictor of poor prognosis in non-small cell lung cancer. Oncol Rep. 2014; 31:2660-68.

21. Xu N, Jia D, Chen W, Wang H, Liu F, Ge H, Zhu X, Song Y, Zhang X, Zhang D, Ge D, Bai C. FoxM1 is associated with poor prognosis of non-small cell lung cancer patients through promoting tumor metastasis. PLoS One. 2013; 8:e59412.

22. Yang DK, Son CH, Lee SK, Choi PJ, Lee KE, Roh MS. Forkhead box M1 expression in pulmonary squamous cell carcinoma: correlation with clinicopathologic features and its prognostic significance. Hum Pathol. 2009; 40:464-70.
23. Yu J, Deshmukh H, Payton JE, Dunham C, Scheithauer BW, Tihan T, Prayson RA, Guha A, Bridge JA, Ferner RE, Lindberg GM, Gutmann RJ, Emnett RJ, et al. Array-based comparative genomic hybridization identifies CDK4 and FOXM1 alterations as independent predictors of survival in malignant peripheral nerve sheath tumor. Clinical cancer research. 2011; 17: 1924-34.

24. Priller M, Poschl J, Abrao L, von Bueren AO, Cho Y-J, Rutkowski S, Kretzschmar HA, Schuller U. Expression of FoxM1 is required for the proliferation of medulloblastoma cells and indicates worse survival of patients. Clinical cancer research. 2011; 17:6791-801.

25. Takata A, Takiguchi S, Okada K, Takahashi T, Kurokawa Y, Yamasaki M, Miyata H, Nakajima K, Mori M, Doki Y. Clinicopathological and prognostic significance of FOXM1 expression in esophageal squamous cell carcinoma. Anticancer Res. 2014; 34:2427-32.

26. Wen N, Wang Y, Wen L, Zhao SH, Ai ZH, Wang Y, Wu B, Lu HX, Yang H, Liu WC, Li Y. Overexpression of FOXM1 predicts poor prognosis and promotes cancer cell proliferation, migration and invasion in epithelial ovarian cancer. J Transl Med. 2014; 12:134.

27. Zhao F, Siu MK, Jiang L, Tam KF, Ngan HY, Le XF, Wong OG, Wong ES, Gomes AR, Bella L, Khongkow P, Lam EW, Cheung AN. Overexpression of forkhead box protein M1 (FOXM1) in ovarian cancer correlates with poor patient survival and contributes to paclitaxel resistance. PLoS One. 2014; 9:e113478.

28. Ning Z, Wang A, Liang J, Xie Y, Liu J, Feng L, Yan Q, Wang Z. USP22 promotes the G1/S phase transition by upregulating FoxM1 expression via $\beta$-catenin nuclear localization and is associated with poor prognosis in stage II pancreatic ductal adenocarcinoma. Int J Oncol. 2014; 45:1594-608.

29. Xia JT, Wang H, Liang LJ, Peng BG, Wu ZF, Chen LZ, Xue L, Li Z, Li W. Overexpression of FOXM1 is associated with poor prognosis and clinicopathologic stage of pancreatic ductal adenocarcinoma. Pancreas. 2012; 41:629-35.

30. Wu XR, Chen YH, Liu DM, Sha JJ, Xuan HQ, Bo JJ, Huang YR. Increased expression of forkhead box M1 protein is associated with poor prognosis in clear cell renal cell carcinoma. Med Oncol. 2013; 30:346.

31. Hui MK, Chan KW, Luk JM, Lee NP, Chung Y, Cheung LC, Srivastava G, Tsao SW, Tang JC, Law S. Cytoplasmic Forkhead box M1 (FoxM1) in esophageal squamous cell carcinoma significantly correlates with pathological disease stage. World J Surg. 2012; 36:90-97.

32. Bella L, Zona S, Nestal de Moraes G, Lam EW. FOXM1: A key oncofoetal transcription factor in health and disease. Semin Cancer Biol. 2014; 29:32-39.

33. Aytes A, Mitrofanova A, Lefebvre C, Alvarez MJ, Castillo-Martin M, Zheng T, Eastham JA, Gopalan A, Pienta KJ, Shen MM, Califano A, Abate-Shen C. Crossspecies regulatory network analysis identifies a synergistic 
interaction between FOXM1 and CENPF that drives prostate cancer malignancy. Cancer Cell. 2014; 25:638-51.

34. Quan M, Cui J, Xia T, Jia Z, Xie D, Wei D, Huang S, Huang Q, Zheng S, Xie K. Merlin/NF2 Suppresses Pancreatic Tumor Growth and Metastasis by Attenuating the FOXM1Mediated Wnt/ $\beta$-Catenin Signaling. Cancer Res. 2015; 75:4778-89.

35. Huang C, Qiu Z, Wang L, Peng Z, Jia Z, Logsdon CD, Le X, Wei D, Huang S, Xie K. A novel FoxM1-caveolin signaling pathway promotes pancreatic cancer invasion and metastasis. Cancer Res. 2012; 72:655-65.

36. Kalin TV, Wang IC, Ackerson TJ, Major ML, Detrisac CJ, Kalinichenko VV, Lyubimov A, Costa RH. Increased levels of the FoxM1 transcription factor accelerate development and progression of prostate carcinomas in both TRAMP and LADY transgenic mice. Cancer Res. 2006; 66:1712-20.

37. Li Q, Zhang N, Jia Z, Le X, Dai B, Wei D, Huang S, Tan $\mathrm{D}$, Xie K. Critical role and regulation of transcription factor FoxM1 in human gastric cancer angiogenesis and progression. Cancer Res. 2009; 69:3501-09.

38. Wang Z, Banerjee S, Kong D, Li Y, Sarkar FH. Downregulation of Forkhead Box M1 transcription factor leads to the inhibition of invasion and angiogenesis of pancreatic cancer cells. Cancer Res. 2007; 67:8293-300.

39. Schonberg DL, Miller TE, Wu Q, Flavahan WA, Das NK, Hale JS, Hubert CG, Mack SC, Jarrar AM, Karl RT, Rosager AM, Nixon AM, Tesar PJ, et al. Preferential Iron Trafficking Characterizes Glioblastoma Stem-like Cells. Cancer Cell. 2015; 28:441-55.

40. Zhang N, Wei P, Gong A, Chiu WT, Lee HT, Colman H, Huang H, Xue J, Liu M, Wang Y, Sawaya R, Xie K, Yung $\mathrm{WK}$, et al. FoxM1 promotes $\beta$-catenin nuclear localization and controls Wnt target-gene expression and glioma tumorigenesis. Cancer Cell. 2011; 20:427-42.

41. Anders L, Ke N, Hydbring P, Choi YJ, Widlund HR, Chick JM, Zhai H, Vidal M, Gygi SP, Braun P, Sicinski P. A systematic screen for CDK4/6 substrates links FOXM1 phosphorylation to senescence suppression in cancer cells. Cancer Cell. 2011; 20:620-34.

42. Francica P, Nisa L, Aebersold DM, Langer R, Bladt F, Blaukat A, Stroka D, Martínez MR, Zimmer Y, Medová M. Depletion of FOXM1 via MET targeting underlies establishment of a DNA damage-induced senescence program in gastric cancer. Clin Cancer Res. 2016; 22:532236.

43. Balli D, Zhang Y, Snyder J, Kalinichenko VV, Kalin TV. Endothelial cell-specific deletion of transcription factor FoxM1 increases urethane-induced lung carcinogenesis. Cancer Res. 2011; 71:40-50.

44. Dai B, Pieper RO, Li D, Wei P, Liu M, Woo SY, Aldape KD, Sawaya R, Xie K, Huang S. FoxM1B regulates NEDD4-1 expression, leading to cellular transformation and full malignant phenotype in immortalized human astrocytes. Cancer Res. 2010; 70:2951-61.

45. Carr JR, Park HJ, Wang Z, Kiefer MM, Raychaudhuri P. FoxM1 mediates resistance to herceptin and paclitaxel. Cancer Res. 2010; 70:5054-63.

46. Liberati A, Altman DG, Tetzlaff J, Mulrow C, Gøtzsche PC, Ioannidis JP, Clarke M, Devereaux PJ, Kleijnen J, Moher D. The PRISMA statement for reporting systematic reviews and meta-analyses of studies that evaluate health care interventions: explanation and elaboration. PLoS Med. 2009; 6:e1000100.

47. Stang A. Critical evaluation of the Newcastle-Ottawa scale for the assessment of the quality of nonrandomized studies in meta-analyses. Eur J Epidemiol. 2010; 25:603-05.

48. Deeks JJ, Altman DG. Analysing and presenting results. In: Higgins JP, Green S, editors. Cochrane Handbook for Systematic Reviews of Interventions 425 Chichester. UK: John Wiley \& Sons; 2006. 